\title{
Genetic identification of hydrocarbons degrading bacteria isolated from oily sludge and petroleum-contaminated soil in Basrah City, Iraq
}

\author{
ENTISAR MUHSON ABOUD ${ }^{1, v v}$, AHMED ABD BURGHAL ${ }^{2, \nu}$, ABDULLAH HAMAD LAFTAH ${ }^{3, v v v}$ \\ ${ }^{1}$ Department of Environment and Pollution, Basrah Engineering Technical College, Sothern Technical University. Istklal st., Basrah, Shatt al-Arab, \\ 24000, Iraq. Tel.: +964-7816000541, vemail: entisarmuhson@ stu.edu.iq \\ ${ }^{2}$ Department of Biology, College of Science, University of Basrah. Basrah, 61001, Iraq. Tel.: +964-7727592620, `email: \\ ahmed.burghal@uobasrah.edu.iq, rwabdullah.lafta@uobasrah.edu.iq
}

Manuscript received: 27 February 2021. Revision accepted: 24 March 2021.

\begin{abstract}
Aboud EM, Burghal AA, Laftah AH. 2021. Genetic identification of hydrocarbons degrading bacteria isolated from oily sludge and petroleum-contaminated soil in Basrah City, Iraq. Biodiversitas 22: 1934-1939. Petroleum is a major problem for environmental pollution due to the extensive use, which can reach all parts of the environment. Contaminated environments are required to identify bacterial diversity that has a remarkable ability to tolerate and biodegrade toxic compounds. The process of oil degradation by microorganisms in their natural environment is affected by certain chemical, physical and biological conditions. Bioremediation techniques are powerful for removing oil pollution, which reflects the ability of microorganisms to destroy organic pollutants. In the current study, six bacterial isolates (S1-S6) were isolated from oil-contaminated soils. mineral salt medium (MSM) was used to carry out biodegradation, crude oil degradation was an evaluation by the gravimetric method. After two weeks of incubation showed S5 isolate the greatest efficiency in oil degradation $53.6 \%$, S1 and S6 also gave good capability degradation (47.31\% and $44.9 \%$ ) respectively, while isolates S2 and S3 gave the lowest percentage. All isolates were identified by $16 \mathrm{~S}$ rDNA amplicons as Pseudomonas stutzeri, Psychrobacter faecalis, Pseudomonas songnenensis, Bacillus cereus, Psychrobacter quanticus strain E9R, and Psychrobacter quanticus strain EA422 according to molecular identification. The current study indicated that hydrocarbon-degrading bacteria specially Psychrobacter can be used to clean soil from crude oil and other industrial discharges.
\end{abstract}

Keywords: Bioremediation, crude oil, degrading bacterial, hydrocarbons, molecular identification

\section{INTRODUCTION}

Petroleum oil contamination is a major environmental pollution problem through the extraction, exploration, oil industries and other human activities (Ehis-Eriakha et al. 2020). Hydrocarbons are the most commonly used fuel in the world, they produce energy for every used (Litvinenko 2020). Clearly, the expanded use of petroleum products caused pollution in all parts of the environment, Therefore, studies are ongoing to diagnose microorganisms with catabolic potentials to degrade these pollutants (Chaillan et al. 2004). Crude oil comprises compounds and other organic compounds, mainly alkanes, cycloalkanes, and aromatic alkanes, which represent $50 \%$ to $80 \%$ of the oil structure. Large numbers of petroleum crude oil and oily sludge are mutagenic and toxic (Koshlaf and Ball 2017). Therefore using microorganisms is stopped the toxicity of oily components, microorganisms have the ability to degraded hydrocarbons such as bacteria, fungi, yeast and microalgae. The ability of microorganisms to degrade hydrocarbons in polluted areas with crude oil has been substantiated (Obuekwe et al. 2009; Allamin et al. 2020). In oil degradation, bacteria have an active part, where many bacteria can break down the oil-contaminated found in water and soil (Brinkrolf et al. 2006; Das and Chandran 2011). The process of crude oil bioremediation by microorganisms in their natural environment is an economical, low-cost and green technology due to certain chemical, physical, and biological conditions and the composition and concentration of the oil pollutant (Deng et al. 2020). Additional factors, including oxygen, salinity pressure, temperature, and moisture, are important variables in the type of environment (Ezeonu et al. 2012; Kumari et al. 2013). Bioremediation processes are effective methods in the removal of oil pollution, which reflects the ability of microorganisms to survive in each area of the biosphere because their enzymatic activity is surprising, promote under a range of environmental condition, then destroy organic pollutants, expected to be an economical and safe way of treating oil pollution (Chandra et al. 2013; Abatenh et al. 2017). To recognize the microbial diversity in the ecosystem usually phylogenetic methods are used. These analyses depending on 16S rRNA genes have a great perception of the essential role in hydrocarbon degradation by microbial diversity and correlation of information between functional catabolic gene and 16S rRNA gene results for utilization of oil ( $\mathrm{Li}$ et al. 2013). In this work, the aim was molecular identification of bacteria community and diversity in the soils exposed to the along-time of oil pollutants using the phylogenetic methodology. This study provides data to understand the catabolization of petroleum compounds by microorganisms in contaminated soils. 


\section{MATERIAL AND METHODS}

\section{Collection of soil samples}

The crude oil contaminated soil and oil sludge samples were collected from five sites near Basrah Refineries Company in Basrah governorate, Iraq (the area is of latitude $30^{\circ} 27^{\prime} 49^{\prime \prime} \mathrm{N}$ and longitude $47^{\circ} 40^{\prime} 27^{\prime \prime} \mathrm{E}$ ) as shown in Figure 1. This company was founded in 1969 through the establishment of the Basrah refinery, which actually began production in 1974. The soil samples were collated under depth $10-20 \mathrm{~cm}$ by sterile tool and put in sterile bags, while sludge samples were collected from sludge located in the same site in sterile containers. Samples were transferred to the laboratory immediately and stored at $4{ }^{\circ} \mathrm{C}$ until tests were carried out. All samples were used for bacteria isolation.

\section{Soil properties}

Soil Texture was measured in the Center of Marine Sciences/University of Basrah depended on the method of Folk (1974), pH and electric conductivity (EC) were measured using $\mathrm{pH}$ electrode (Sartorius, Germany), moisture was measured as described by Eaton et al. (2005), total organic carbon (TOC), total carbon (TC) and NPK were measured using method of APHA (2005) and Baird (2017).

\section{Bacterial strains isolation}

The degrading bacterial strains were isolated on the nutrient agar medium by using spread plate technique, a serial dilution of samples was prepared including $10^{-1}-10^{-6}$ dilutions by dissolving $1 \mathrm{gm}$ of oily soil and sludge with $100 \mathrm{~mL}$ of sterile saline solution into a flask and incubated in an orbital shaker at $120 \mathrm{rpm}$ for 15 minutes. The mixture was left to settle into the bottom, $1 \mathrm{~mL}$ of each suspension transferred into a test tube containing $9 \mathrm{~mL}$ of dilution solution to prepare serially diluted solution . $0.1 \mathrm{~mL}$ from the diluted sample was spread with a glass L shape rod onto plate with nutrient agar and incubated for 24-48 hours at $30 \pm 2^{\circ} \mathrm{C}$ (Kannan et al. 2018). After incubation, the bacteria colonies were checked and pure colonies were selected, each isolate was labeled and maintained at $4{ }^{\circ} \mathrm{C}$ for further studies on fresh sterile nutrient agar medium. The isolates were identified by gram staining and morphological (shape and color of the colony) and biochemical characteristics were performed, then the colonies were kept in slant test tubes and stored at $4{ }^{\circ} \mathrm{C}$ until the following tests are carried out (Barathi and Vasudevan 2001).

\section{Biodegradation of crude oil in liquid MSM}

After the bacterial strains were isolated and named S1 to S6, the efficiency of oil biodegradation of these isolates were tested using the Mineral Salt Media (MSM), that consist of $\mathrm{g} / \mathrm{L} \mathrm{NH}_{4} \mathrm{NO}_{3}, 4 ; \mathrm{MgSO}_{4}, 0.5 ; \mathrm{CaCl}_{2}, 0.2$; $\mathrm{KH}_{2} \mathrm{PO}_{4}, 0.5 ; \mathrm{K}_{2} \mathrm{HPO}_{4}, 0.5$ and $1 \mathrm{~mL}$ trace element solution containing per $100 \mathrm{~mL}$ : $\mathrm{CuSO}_{4}, 0.1 \mathrm{~g} ; \mathrm{CaCl}_{2}, 0.05 \mathrm{~g}$; $\mathrm{MnSO}_{4}, 0.178 \mathrm{~g} ; \mathrm{ZnSO}_{4}, 0.042 \mathrm{~g}$. All of these components were homogenized by a magnetic stirrer, $\mathrm{pH} 7 \pm 0.2$ adjusted and sterilized by autoclave. Isolates were activated in 10 $\mathrm{mL}$ nutrient broth medium. Erlenmeyer flasks of $250 \mathrm{~mL}$ were implied containing $100 \mathrm{~mL}$ of MSM were prepared, the isolates inoculum $(5 \% \mathrm{v} / \mathrm{v})$ were added to media in addition to the $2 \mathrm{~mL}$ of commercial light crude oil. Control samples containing MSM and crude oil without adding bacterial inoculum, all samples were incubated aerobically with shaker incubator at rotation speed $120 \mathrm{rpm}$ at $32{ }^{\circ} \mathrm{C}$ for 2 weeks (Sarshad et al. 2015).

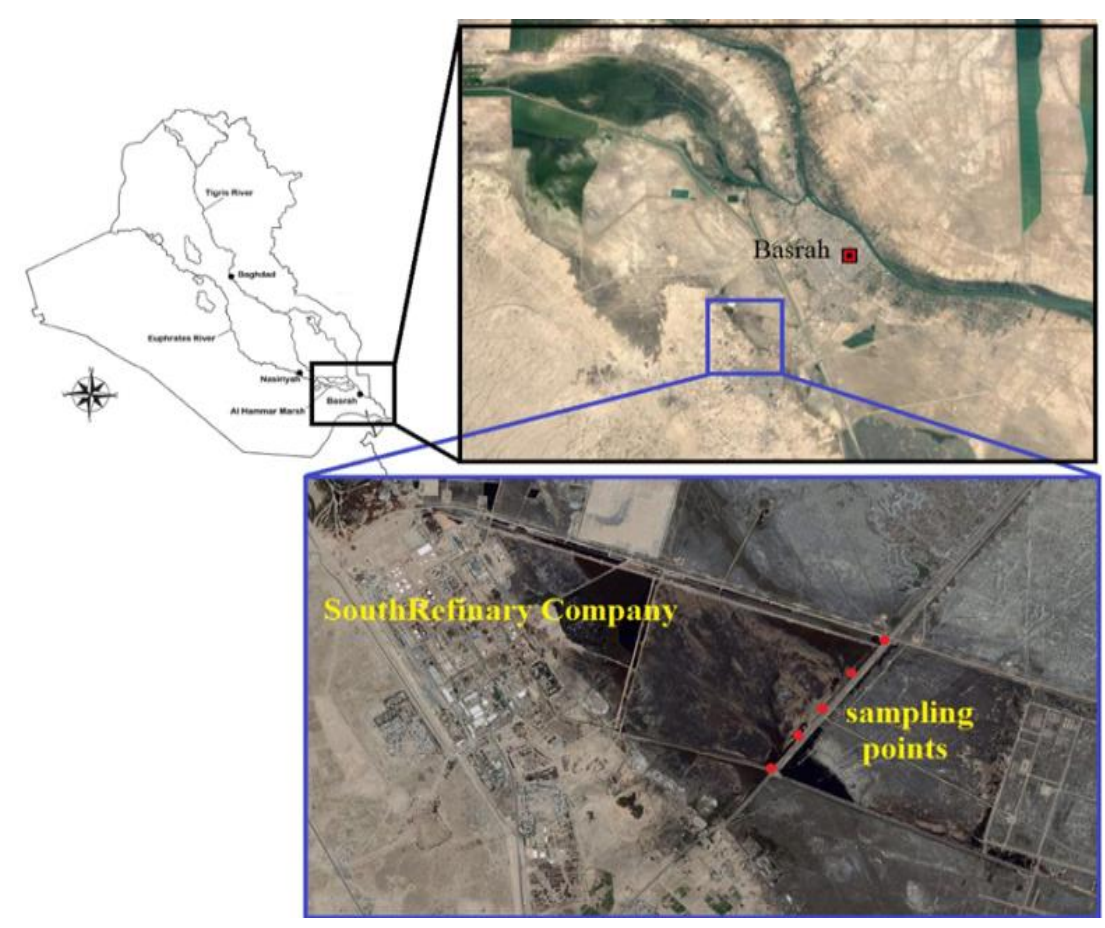

Figure 1. Map of samples collection site (red points represent mains location for sample collection) 


\section{Assessment of bacterial oil biodegradation}

Crude oil degradation was evaluated by the gravimetric method. After two weeks of incubation, degrading processes appeared in the flasks at different proportions, after that the contents of the flask were placed in a separating funnel to extract the residual oil by adding 15 $\mathrm{mL}$ of chloroform to the separation funnel components three times to get all the remaining oil, the residual oil was fell down into Pre-weighed screw cap and then chloroform was vaporized on the hot plate under a fume hood, screws were cooled and weighed again to extract the weight difference. Oil in the flask control was also extracted in the same way (Bagherzadeh et al. 2008). The percentage of fractions was calculated and recorded. Gravimetric value for extracted oil was weighed for further calculation using the gravimetric method. The percent of Oil degraded was calculated as follows: (Allamin et al. 2020).

Weight of extracted crude oil $=$ (weight of container after extraction oil - weight of the empty container).

Removal of crude oil $\%=($ Control - sample of crude extracted) /control x 100

\section{Molecular identification of isolates}

Genomic DNA was extracted from six high-efficiency bacteria isolates by using Promega Genomic DNA isolation extraction kit according to manufacturer instructions (Promega, USA) bacteria were the following universal primers: 27F (AGAGTTTGATCMTGGCTCAG) (Lane 1991) and 1492R (TACGGYTACCTTG TTACGACTT) (Turner et al. 1999) to obtain products by thermal cycler (Bioneer, South Korea). The fragments of 16SrDNA genes amplification were performed by using a master mix of PCR (Promega, USA) contains a final volume of $50 \mu \mathrm{l}$, two primers $(27 \mathrm{~F}$ and $1492 \mathrm{R}), 2 \mathrm{x}$ master mix and dd. $\mathrm{H}_{2} \mathrm{O}$. Thermal cycler conditions including: first denaturation step at $94^{\circ} \mathrm{C}$ for $2 \mathrm{~min}$ followed by 35 cycles of second denaturation step at $94{ }^{\circ} \mathrm{C}$ for $1 \mathrm{~min}$, step of annealing at 55 ${ }^{\circ} \mathrm{C}$ for 30 s then extension step at $72{ }^{\circ} \mathrm{C}$ for $1 \mathrm{~min}$ and final extension for $10 \mathrm{~min}$ at $72^{\circ} \mathrm{C}$ (Liu et al. 2007). Amplified
16S rRNA gene products of approximately 1500 bp were confirmed by $2 \%(\mathrm{w} / \mathrm{v})$ agarose gel and compared with 100 bp DNA ladder and visualized under ultraviolet radiation after staining with $0.05 \mu \mathrm{l}(0.5 \mathrm{mg} / \mathrm{mL})$ ethidium bromide (Thermo Fisher Scientific, USA). The products of $16 \mathrm{~S}$ rRNA genes were transferred to Macrogen company in South Korea for sequencing. The $16 \mathrm{~S}$ rDNA sequences were edited, analyzed and matched with sequences of the database in the National Center for Biotechnology Information (http//www.ncbi.nlm.nih.gov/BLAST) to evaluate the homology scores and detection of bacterial strains (Katoh et al. 2002).

\section{RESULTS AND DISCUSSION}

\section{Soil properties}

The results of the physical and chemical properties of the oil-contaminated soil were illustrated in Table (1). Which shows variation in parameters between soil collected from five sites. The $\mathrm{pH}$ value was range 7.5-8.66, percentage of soil moisture was $2.4-9.9 \%$, EC of soil 1120 $1616 \mu \mathrm{S} / \mathrm{cm}$, the texture of soil according to the content type was belong to sandy loam, $10 \%$ clay $(<0.002 \mathrm{~mm})$, $77 \%$ silt $(0.02-0.002 \mathrm{~mm})$, and $13 \%$ sand $(0.02-2.0) \mathrm{mm}$. While the values of \%TOC ranged from $1.35-2.45$ and $\%$ TC ranged 1.039-1.886, N.P.K. levels in soil were 25.8$38 \mathrm{mg} . \mathrm{kg}^{-1}(\mathrm{~N}),(2.3-6.8) \mathrm{mg} \mathrm{kg}-1(\mathrm{P}),(0.45-1.43) \mathrm{mg} / \mathrm{kg}$ (K) respectively, the indigenous bacteria were $\left(1.3 \times 10^{4}\right.$ $\left.4.2 \times 10^{4}\right) \mathrm{cfu} / \mathrm{g}$.

After the primary isolation of bacteria from hydrocarbons contaminated samples and subculture on nutrient Agar, six colonies were selected from plates, three colonies were selected from soil samples plates, and three colonies were selected from sludge samples plates. The six colonies were labeled (S, S2, S3, S4, S5, and S6). Gram staining was used to identify the bacterial colonies showed five isolates were gram-negative, while one isolate (S4) was gram-positive spores forming (Table 2).

Table 1. Physical, chemical and microbiological features of experimental soil

\begin{tabular}{|c|c|c|c|c|c|}
\hline Parameter & SITE 1 & SITE 2 & SITE 3 & SITE 4 & SITE 5 \\
\hline $\mathrm{pH}$ & $7.8 \pm 0.15$ & $7.5 \pm 0.1$ & $8.66 \pm 0.55$ & $8.52 \pm 0.04$ & $8.4 \pm 0.3$ \\
\hline Soil moisture $(\%)$ & $3.4 \pm$ & $2.4 \pm$ & $1.5 \pm$ & $9.9 \pm$ & $2.8 \pm$ \\
\hline $\mathrm{EC}(\mu \mathrm{S} / \mathrm{cm})$ & 1145 & 1120 & 1547 & 1616 & 1134 \\
\hline Texture soil: & Sandy loamy & Sandy loamy & Sandy loamy & Sandy loamy & Sandy loamy \\
\hline Sand (\%) 10; Silt (\%) 77; Clay (\%) 13 & & & & & \\
\hline TPHs $\mathrm{g} / \mathrm{kg}$ & 36.3 & 34.6 & 22.7 & 41.6 & 13.5 \\
\hline Organic TOC matter $(\%)$ & 1.755 & 2.05 & 1.35 & 1.67 & 2.45 \\
\hline Organic C (TC)\% & 1.235 & 1.578 & 1.039 & 1.286 & 1.887 \\
\hline Total N (mg/kg) & 38.5 & 24.3 & 35.3 & 28.6 & 25.8 \\
\hline $\mathrm{P}(\mathrm{mg} / \mathrm{kg})$ & 6.8 & 5.4 & 2.3 & 2.6 & 5.7 \\
\hline $\mathrm{K}(\mathrm{mg} / \mathrm{g})$ & 0.72 & 1.04 & 0.67 & 0.45 & 1.34 \\
\hline THBC cfu/g & $3.2 \times 10^{4}$ & $4.2 \times 10^{4}$ & $1.2 \times 10^{4}$ & $1.3 \times 10^{4}$ & $2.3 \times 10^{4}$ \\
\hline
\end{tabular}




\section{Assessment of bacterial biodegradation}

The results of oil biodegradation by bacterial strains showed that six strains isolated from oil-contaminated sites had the ability for hydrocarbons degradation after ten days of incubation on mineral salt media. The extraction of remaining crude oil from media indicated the capability of oil-removing as showing in Figure 1, where the isolate S5 achieved the highest efficiency for oil degradation rate of $53.6 \%, \mathrm{~S} 1$ and $\mathrm{S} 6$ also gave good degradation rate of (47.3\% and $44.9 \%$ ) respectively, while isolates $\mathrm{S} 2$ and $\mathrm{S} 3$ gave the lowest percentage of oil degradation $14.6 \%$.

\section{Molecular identification of isolates}

The isolates (S1, S2, S3, S4, S5, and S6) were identified according to 16 SrDNA amplification. Based on the blasting results, isolates $\mathrm{S} 1$ and $\mathrm{S} 3$ belong to Pseudomonas stutzeri and Pseudomonas songnenensis species with $99 \%$ and $98 \%$ identity respectively. Isolates $\mathrm{S} 2, \mathrm{~S} 5$ and $\mathrm{S} 6$ belong to Psychrobacter genus, These isolates detected as Psychrobacter faecalis 99\%, Psychrobacter quanticus strain E9R 99\%, and Psychrobacter quanticus strain EA422 100\%, while isolate S4 closely related 99\% with Bacillus cereus (Table 2).

In the current study Phylogenetic tree was constructed based on sequences of oil-degrading isolates from the NCBI- BLAST. The results of the phylogenetic tree placed three Psychrobacter isolates into two subgroups, The first subgroup included Psychrobacter quanticus while the second sub-group included Psychrobacter faecalis. two Pseudomonas isolates separated into two subgroups too included (Pseudomonas stutzeri and Pseudomonas songnenensis). In addition to one Bacillus isolate as explained in (Figure 2).

The physical and chemical parameters of the oilcontaminated sites are essential because they indicate the gradient of biological degradation and be used to assess treatment or weathering that occurs naturally in the environment (Devatha et al 2019). Microbes are acting as vital against when the contaminants have access to a diversity of substances to aid them to produce energy for the growth of cells. Many factors are affected on the bioremediation efficiency including the physicochemical properties of soil, the concentration of pollutants, and their accessibility to microbes (Truskewycz et al. 2019). Hydrocarbon pollutant treatment by bioremediation is an efficient strategy to remove soil contaminated, aiming to use microorganisms to solve this problem. This process has a lot of benefits to become very well-known in the environment and environmentally friendly by the possibility of using the materials resulting from the treatment as a source of energy, provide less toxic substances and less impact on the environment, the bioremediation technique has been used by many researchers and interested in these technologies (Mansur et al. 2016; Abatenh et al. 2017).

Grow on highly hydrocarbons concentration or refractory compounds its feature of Pseudomonas and Bacillus spp., this is due to their possession of a group of enzymes that analyze chemical compounds. The possession of this natural bacterial capacity enables them to secrete enzymes to analyze when they need to do metabolic processes, leading to hydrocarbon biodegradation (Naik and Duraphe 2012). Several studies have reported the ability of various bacterial species to degrade hydrocarbons (Anaukwu et al. 2016; Wang et al. 2020; Perdigão et al. 2021). Ehis-Eriakha et al. (2020) report about the potential degrader's genes on a plasmid and chromosomal DNA in bacterial strains isolated from oil-polluted soil in Nigeria genetically identified, indicated 16 isolates have degradation activity in a liquid mineral medium. The highest potential for crude oil degradation by Bacillus cereus due to present various plasmids and chromosomes catabolic genes.

Table 2. Summarized the gram stain and morphological characteristics

\begin{tabular}{cccc}
\hline Isolate & Gram stain & Cell shape & Colony color \\
\hline S1 & G-ve & Rod & Whitish(creamy) \\
S2 & G-ve & Rod & Whitish(creamy) \\
S3 & G-ve & Rod & Whitish(creamy) \\
S4 & G+ve & Short rod & Whitish(creamy) \\
S5 & G-ve & Rod & Whitish(creamy) \\
S6 & G-ve & Rod & Whitish(creamy) \\
\hline
\end{tabular}

Table 3. List of oil-degrading strains identified according to 16SrDNA sequences

\begin{tabular}{llc}
\hline Isolates & \multicolumn{1}{c}{ Strains as in GenBank } & $\begin{array}{c}\text { Max. } \\
\text { identity } \\
(\%)\end{array}$ \\
\hline S1 & Pseudomonas stutzeri strain DItb 1006-10R & $99 \%$ \\
S2 & Psychrobacter faecalis strain C18 16SR & $99 \%$ \\
S3 & Pseudomonas songnenensis ESF-139 7R & $98 \%$ \\
S4 & Bacillus cereus strain BY27 & $99 \%$ \\
S5 & Psychrobacter quanticus strain E9R & $99 \%$ \\
S6 & Psychrobacter quanticus strain EA422 & $100 \%$ \\
\hline
\end{tabular}

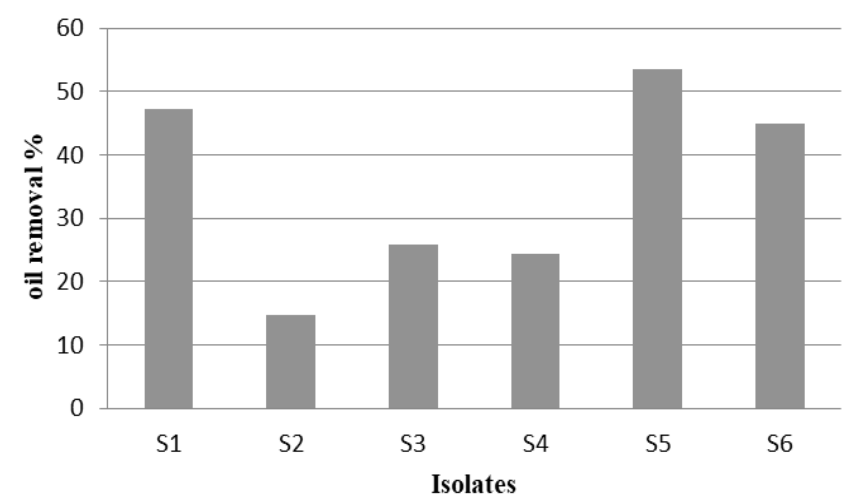

Figure 1. percentage of oil removing by bacterial isolates to TPHs after biodegradation through 14 days 


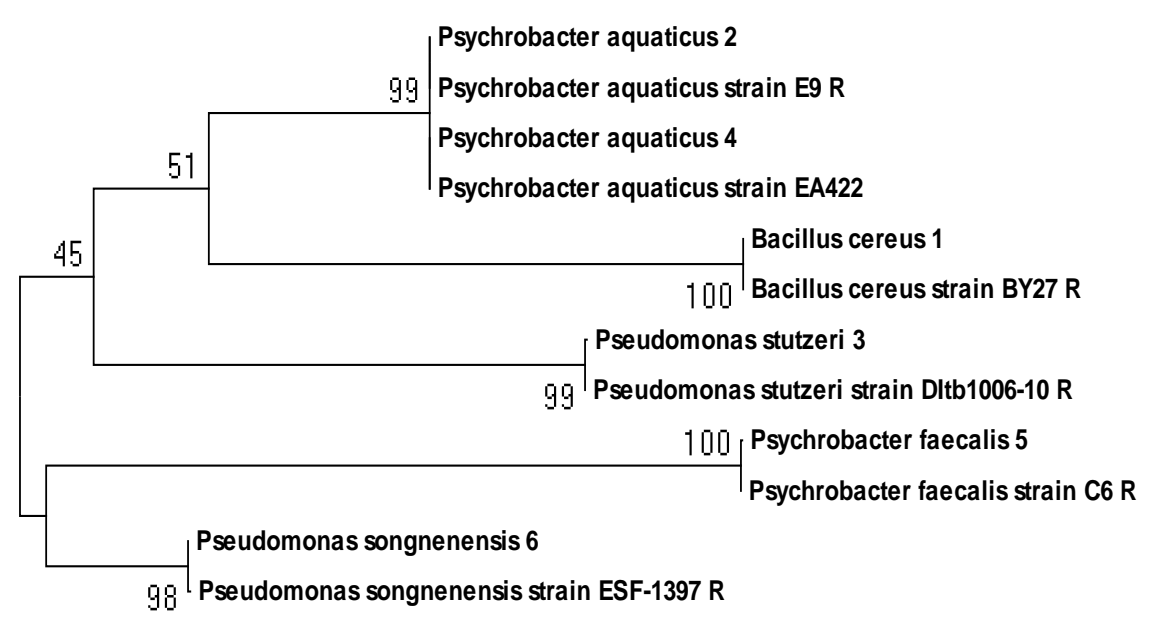

Figure 2. The neighbor-Joining phylogenetic tree created by MEGA 6 program, showed the relationships between 6 different isolated from (Soil and sludge contaminated with hydrocarbons) in this study and 6 reference strains $(\mathrm{R})$.

Psychrobacter is one of the isolates, that it's not expected to show this biological activity because some of the species it is a pathogenic bacteria for humans such as Psychrobacter immobilis has been isolated from the eye, and other bacterial infections, these bacteria may be the cause of opportunistic infections. The clinical articulation of this species is practically unknown, although it has been isolated in patients with meningitis and other infections. In the current study, these bacteria gave the highest percentage removal of oil as shown in Figure 1. Subsequently indicated several studies, in Antarctic habitats, Psychrobacter is widely distributed in ornithogenic soils, anchor, grease ice, and salt lake (Maruyama et al. 2000; Ayala-del-Río et al. 2010; Kashi et al. 2020). Psychrobacter is a genus within the GammaProteobacteria. The presence of some Psychrobacter in crude oil-contaminated soil and sludge has not been detected in scientific research therefore this study might the first time confirmed their ability to degrade hydrocarbons.

In the present study, this bacterium was isolated and identified from soils contaminated with hydrocarbons, confirms their ability to degrade hydrocarbons and gave the highest percentage in the removal and biodegradation of oil compared with other isolates. A study from Romaniuk et al. (2018) on Psychrobacter showed that it has tolerance to zinc, chromium, copper, and other heavy metals and resistance to arsenate. Psychrobacter cold-adapted indigenous microorganisms play a significant role in the in situ biodegradation of hydrocarbons in cold environments, where ambient temperatures often coincide with their growth temperature range (Margesin and Schinner 2001). However, since soil and sludge were collected from old petroleum contaminated sites, Oil concentration was high, the deterioration of oil has usually enhanced with changes in oil concentration, which is compatible with the results of Boshui et al. (2012).

Psychrobacter spp. prefer to grow at $20^{\circ} \mathrm{C}$ or down, but many strains may be tolerant salinity, where the ability to grow in concentrations of $\mathrm{NaCl}$ may reach more than $12 \%$ (w/v), but these strains do not have the potential for hydrocarbon-degradation (Azevedo et al. 2013), the existence of several dangerous xenobiotics such as hydrocarbons, in some environments, increased occurrence of Psychrobacter spp, which can utilize these compounds. It has been observed in some species of Psychrobacter, a difference in biological activity, tends when the source of nitrogen and carbon is changed towards higher molecular weight hydrocarbons. The reason for its tolerance to change in the chemical composition of the medium and harsh conditions is its high adaptability to withstand abnormal conditions.

In conclusion, studying the diversity of bacteria that have the ability to biodegrade hydrocarbons is very important as the first stage in the treatment of petroleum hydrocarbons pollution. Six strains of bacteria were isolated from petroleum-contaminated soil. These strains are capable of using hydrocarbons in crude oil as the sole carbon source. The efficiency of hydrocarbons degradation after 10 days of incubation ranged from $14.63 \%$ to $53.6 \%$. the isolates S1, S2, S3, S4, S5, and S6 were identified as Pseudomonas stutzeri, Psychrobacter faecalis, Pseudomonas songnenensis, Bacillus cereus, Psychrobacter quanticus strain E9R, Psychrobacter quanticus strain EA422 respectively. The ability to removing toxic substances from the environment, which is an effective advanced technology was successfully proved.

\section{ACKNOWLEDGEMENTS}

The authors are grateful for the support by the College of Science, Basrah University in Iraq for the post-graduate project, and we acknowledge all facilities provided by the Basrah refineries company for sample collection and database. 


\section{REFERENCES}

Abatenh E, Gizaw B, Tsegaye Z, Wassie M. 2017. The role of microorganisms in bioremediation-A review. Open J Environ Biol 2 (1): 038-046. DOI: 10.17352/ojeb.000007

Allamin IA, Halmi MIE, Yasid NA, Ahmad SA, Abdullah SRS, Shukor Y. 2020. Rhizodegradation of petroleum oily sludge-contaminated soil using Cajanus cajan increases the diversity of soil microbial community. Sci Rep 10 (1): 1-11. DOI: 10.1038/s41598-020-60668-1

Anaukwu CG, Ezemba CC, Anakwenze VN, Agu KC, Nwankwegu AS, Okeke BC, Awah NS. 2016. Influence of anionic, cationic and nonionic surfactants on growth of hydrocarbon utilizing bacteria. Am J Curr Microbiol 4 (1): 10-16.

APHA. 2005. Standard methods for the examination of water and wastewater. Am Public Heal Assoc Washington, DC, USA.

Ayala-del-Río HL, Chain PS, Grzymski JJ, Ponder MA, Ivanova N, Bergholz PW, Di Bartolo G, Hauser L, Land M, Bakermans C, Rodrigues D. 2010. The genome sequence of Psychrobacter arcticus 273-4, a psychroactive Siberian permafrost bacterium, reveals mechanisms for adaptation to low-temperature growth. Appl Environ Microbiol 76 (7): 2304-2312. DOI: 10.1128/AEM.02101-09

Azevedo JSN, Correia A, Henriques I. 2013. Molecular analysis of the diversity of genus Psychrobacter presents within a temperate estuary. FEMS Microbiol Ecol 84 (3): 451-460. DOI: 10.1111/1574 6941.12075

Bagherzadeh NA, Shoja AS, Hashemi NS. 2008. Biodegradation of used engine oil using mixed and isolated cultures. Int J Environ Res 2 (4): 431-440.

Baird RB. 2017. Standard Methods for the Examination of Water and Wastewater, 23rd. Water Environment Federation, American Public Health Association, American Water Works Association.

Barathi S, Vasudevan N. 2001. Utilization of petroleum hydrocarbons by Pseudomonas fluorescens isolated from a petroleum-contaminated soil. Environ Int 26 (5-6): 413-416. DOI: 10.1016/s01604120(01)00021-6

Boshui CB, Nan Z, Jiang W, Jiu W, Jianhua F. 2012. Biodegradation of petroleum hydrocarbon by Pseudomonas aeruginosa. China Petro Proc Petrochem Technol 14: 66-70.

Brinkrolf K, Brune I, Tauch A. 2006. Transcriptional regulation of catabolic pathways for aromatic compounds in Corynebacterium glutamicum. Genet Mol Res 5 (4): 773-789.

Chaillan F, Le Flèche A, Bury E, Phantavong YH, Grimont P, Saliot A, Oudot J. 2004. Identification and biodegradation potential of tropical aerobic hydrocarbon-degrading microorganisms. Res Microbiol 155 (7): 587-595. DOI: 10.1016/j.resmic.2004.04.006

Chandra S, Sharma R, Singh K, Sharma A. 2013. Application of bioremediation technology in the environment contaminated with petroleum hydrocarbon. Ann Microbiol 63 (2): 417-431. DOI 10.1007/s13213-012-0543-3

Das N, Chandran P. 2011. Microbial degradation of petroleum hydrocarbon contaminants: an overview. Biotechnol Res Int 2011: 941810. DOI: $10.4061 / 2011 / 941810$

Deng Z, Jiang Y, Chen K, Gao F, Liu X. 2020. Petroleum depletion property and microbial community shift after bioremediation using Bacillus halotolerans T-04 and Bacillus cereus 1-1. Front Microbiol 11: 353. DOI: $10.3389 /$ fmicb.2020.00353

Devatha CP, Vishal AV, Rao JPC. 2019. Investigation of physical and chemical characteristics on soil due to crude oil contamination and its remediation. Appl Water Sci 9: 89. DOI: 10.1007/s13201-019-0970-4

Eaton AD, Clesceri LS, Rice EW, Greenberg AE, Franson MAH. 2005. Standard methods for the examination of water and wastewater centennial edition, 21st edn. American Public Health Association, Washington. DC

Ehis-Eriakha CB, Chikere CB, Akaranta O. 2020. Functional Gene Diversity of Selected Indigenous Hydrocarbon-Degrading Bacteria in Aged Crude Oil. Int J Microbiol 2020. DOI: 10.1155/2020/2141209

Ezeonu CS, Tagbo R, Anike EN, Oje OA, Onwurah INE. 2012. Biotechnological tools for environmental sustainability: prospects and challenges for environments in Nigeria - a standard review. Biotechnol Res Int 2012. DOI: 10.1155/2012/450802

Folk RL. 1974. Petrology of sedimentary rocks. USA Hemphill's, Austin Folk, Texas.

Kannan MN, Sethi S, Badoni A, Chamoli V, Bahuguna NC. 2018. Isolation and characterization of bacterial isolates from agriculture field soil of Roorkee region. J Pharm Phytochem 5: 108-110.
Kashi FJ, Owlia P, Amoozegar MA, Yakhchali B, Kazemi B. 2020. Diversity of cultivable microorganisms in the eastern part of Urmia salt lake, Iran. J Microbiol Biotechnol Food Sci 9 (4): 36-43. DOI:10.15414/jmbfs.2014.4.1.36-43

Katoh K, Misawa K, Kuma K, Miyata T. 2002. MAFFT: a novel method for rapid multiple sequence alignment based on fast Fourier transform. Nucleic Acids Res 30 (14): 3059-3066. DOI: $10.1093 / \mathrm{nar} / \mathrm{gkf} 436$

Koshlaf E, Ball AS. 2017. Soil bioremediation approaches for petroleum hydrocarbon polluted environments. AIMS Microbiol 3 (1): 25-49. DOI: $10.3934 /$ microbiol.2017.1.25

Kumari N, Vashishtha A, Saini P, Menghani E. 2013. Isolation, identification and characterization of oil-degrading bacteria isolated from the contaminated sites of Barmer, Rajasthan. Int J Biotechnol Bioeng Res 4 (5): 429-436.

Lane DJ. 1991. 16S/23S rRNA sequencing in: Nucleic acid techniques in bacterial systematic. (eds). Stackebrandt E, Goodfellow M. John Wiley \& Sons, Ltd. Chichester England.

Li H, Wang X-L, Mu B-Z, et al. 2013. Molecular detection, quantification and distribution of alkane-degrading bacteria in production water from low-temperature oilfields. Int Biodeterior Biodegrad 76: 49-57. DOI: $10.1016 / \mathrm{j}$.ibiod.2012.06.007

Litvinenko V. 2020. The role of hydrocarbons in the global energy agenda: The focus on liquefied natural gas. Resources 9 (5): 59. DOI: $10.3390 /$ resources 9050059

Liu J, Xie X, Xiao S, Wang X, Zhao W, Tian Z. 2007. Isolation of Leptospirillum ferriphilum by single-layered solid medium. J Cent South Univ Technol 14 (4): 467-473. DOI: 10.1007/s11771-0070091-3

Mansur AA, Taha M, Shahsavari E, Haleyur N, Adetutu EM, Ball AS. 2016. An effective soil slurry bioremediation protocol for the treatment of Libyan soil contaminated with crude oil tank bottom sludge. Int Biodeterior Biodegrad 115: 179-185. DOI: 10.1016/j.ibiod.2016.08.015

Margesin R, Schinner F. 2001. Biodegradation and bioremediation of hydrocarbons in extreme environments. Appl Microbiol Biotechnol 56 (5): 650-663. DOI: 10.1007/s002530100701.

Maruyama A, Honda D, Yamamoto H, Kitamura K, Higashihara T. 2000. Phylogenetic analysis of psychrophilic bacteria isolated from the Japan Trench, including a description of the deep-sea species Psychrobacter pacificensis sp. nov. Int J Syst Evol Microbiol 50 (2): 835-846. DOI: 10.1099/00207713-50-2-835.

Naik MG, Duraphe MD. 2012. Review paper on-Parameters affecting bioremediation. Int J life Sci pharma Res 2 (3): L77-L80.

Obuekwe CO, Al-Jadi ZK, Al-Saleh ES. 2009. Hydrocarbon degradation in relation to cell-surface hydrophobicity among bacterial hydrocarbon degraders from petroleum-contaminated Kuwait desert environment. Int Biodeterior Biodegrad 63 (3): 273-279. DOI: 10.1016/j.ibiod.2008.10.004

Perdigão R, Almeida CMR, Santos F, Carvalho MF, Mucha AP. 2021. Optimization of an autochthonous bacterial consortium obtained from beach sediments for bioremediation of petroleum hydrocarbons. Water 13 (1): 66. DOI: 10.3390/w13010066

Romaniuk K, Ciok A, Decewicz P, Uhrynowski W, Budzik K, Nieckarz M, Pawlowska J, Zdanowski MK, Bartosik D, Dziewit L. 2018. Insight into heavy metal resistome of soil psychrotolerant bacteria originating from King George Island (Antarctica). Polar Biol 41 (7): 1319-1333. DOI: $10.1007 / \mathrm{s} 00300-018-2287-4$

Sarshad DD, Shiraf N, Arjunan, SE. 2015. Isolation and characterization of hydrocarbon-degrading bacteria. Int J Pharm Bio Sci 6 (3): (B) 469-478.

Truskewycz A, Gundry TD, Khudur LS, Kolobaric A, Taha M, AburtoMedina A, Ball AS, Shahsavari E. 2019. Petroleum hydrocarbon contamination in terrestrial ecosystems-fate and microbial responses. Molecules 24 (18): 3400. DOI: 10.3390/molecules24183400

Turner S, Pryer KM, Miao VPW, Palmer JD. 1999. Investigating deep phylogenetic relationships among cyanobacteria and plastids by small subunit rRNA sequence analysis 1. J Eukaryot Microbiol 46 (4): 327 338. DOI: $10.1111 / \mathrm{j} .1550-7408.1999 . t b 04612 . x$

Wang W, Li Z, Zeng L, Dong C, Shao Z. 2020. The oxidation of hydrocarbons by diverse heterotrophic and mixotrophic bacteria that inhabit deep-sea hydrothermal ecosystems. ISME J 14 (8): 19942006. DOI: 10.1038/s41396-020-0662-y 